Article

\title{
Novel Microsatellite Markers of Meretrix petechialis and Cross-species Amplification in Related Taxa (Bivalvia: Veneroida)
}

\author{
Jung-Ha Kang ${ }^{1}$, Byeng-Hak Kim ${ }^{2}$, Jung-Youn Park ${ }^{1}$, Jung-Mi Lee ${ }^{3}$, Ji-Eun Jeong ${ }^{4}$, \\ Jun-Sang Lee ${ }^{5}$, Hyun-Sook Ko ${ }^{6}$ and Yong-Seok Lee ${ }^{4, *}$
}

1 Biotechnology Research Division, NFRDI, Busan 619-705, Korea;

E-Mails: kjh0124@nfrdi.go.kr (J.-H.K.); jypark@nfrdi.go.kr (J.-Y.P.)

2 Southwest Sea Fisheries Research Institute, NFRDI, Yeosu 556-823, Korea;

E-Mail: bhkim@nfrdi.go.kr

3 Gyeongsangnam-do Fisheries Resources Research Institute, Tongyoung 650-974, Korea;

E-Mail: leebeauty62@korea.kr

4 Department of Parasitology, College of Medicine and UHRC, Inje University, Busan 614-735, Korea;

E-Mail: jje2010@inje.ac.kr

5 Institute of Environmental Research, Kangwon National University, Chunchon 200-701, Korea;

E-Mail: sljun@kanwon.ac.kr

6 Department of Biological Science, Silla University, Busan 617-736, Korea;

E-Mail: hsko@sila.ac.kr

* Author to whom correspondence should be addressed; E-Mail: Genetics@korea.kr;

Tel.: +82-51-720-2462.

Received: 17 September 2012; in revised form: 11 November 2012 / Accepted: 14 November 2012 / Published: 28 November 2012

Abstract: The Asian hard clam, Meretrix petechialis, is an economically important bivalve, but its catch and population sizes are decreasing rapidly, owing to many factors, including large-scale reclamation of its natural habitat on the western coast of the Korean peninsula. Attempts to restore the resources and production of this species require genetic structure and diversity information. In this study, we developed 15 microsatellite markers from a partial genomic library enriched in GT repeats. Nine of these markers were polymorphic, with an average allele number of six, and six were monomorphic in 95 tested individuals. No linkage disequilibrium was found between any pair of loci $(p>0.05)$, and deviations from the Hardy-Weinberg equilibrium (HWE) test showing excess of 
heterozygotes was observed in only one of nine loci. In addition, no null alleles or genetic differentiation between two tested populations were detected. A cross-species amplification in 12 species of four families resulted in two M. petechialis-specific loci and three possible universal markers. This information will be useful in the future development of high-quality artificial seedlings and sustainable resource management.

Keywords: Meretrix; microsatellite; cross-species; Veneroida

\section{Introduction}

The genus Meretrix, commonly known as Asian hard clams, is distributed in the West Pacific, Asia, and the Indian Ocean [1] and is an important commercial bivalve in East and Southeast Asia and East Africa [2]. These clams inhabit tidal flats, estuaries and sandy beaches, which are well developed on the southern and western coasts of the Korean Peninsula. Most of the members of the genus are important fishery resources.

Among the nine recognized species, two very closely related species, M. lusoria and M. petechialis, occur naturally along the west coast of the Korean Peninsula and China [3] and are economically very important. Meretrix lusoria inhabits the southern coast of Korea, and M. petechialis occupies the western coasts, with the border between them located along the southwestern coast of Korea from Gangjin Bay to Baeksu [4].

As with other clams, natural populations of $M$. petechialis have decreased drastically on the Korean Peninsula because of ocean pollution and reclamation. The annual production of $M$. petechialis in Korea was $11,705 \mathrm{M} / \mathrm{T}$ in 1971 , but only $1454 \mathrm{M} / \mathrm{T}$ in 2008 . Among the many factors affecting the decrease of M. petechialis in Korea, the reclamation of the Saemangeum area, with a $33 \mathrm{~km}$ long dike, has had a great effect, as this area is the most productive site of M. petechialis in the country [5].

In response to the decrease in natural habitat and production of $M$. petechialis, aquaculture production and seed release to restore natural resources have become necessary. The aquaculture of this species has been long attempted, and complete culturing, including reproductive control, captive spawning, hatching, and larval and juvenile rearing, has only recently become possible on a small scale.

Future production of high-quality seedlings for aquaculture and release depends on information regarding the genetic structure and diversity of the species, which can be provided by using reliable genetic markers. However, despite their economic importance, few phylogenetic and population genetic studies of the genus Meretrix have been conducted.

Mitochondrial DNA (mtDNA) is the most commonly used target DNA for taxonomic and phylogenetic purposes because of its simple maternal inheritance, absence of recombination and high substitution rate [6]. However, a very high level of sex-associated mtDNA heteroplasmy and unusual doubly uniparental inheritance (DUI) have been reported from different bivalve families, including the Veneridae $[7,8]$. Thus, special care in the taxonomy of bivalves is required.

In contrast to mtDNA markers typically used for species identification, co-dominant genetic markers, such as microsatellite (MS) markers, are useful for genetic structure analysis, family identification and parentage assignment. The combination of microsatellite markers and genetic 
improvements in breeding has considerably improved shellfish aquaculture, including oysters, mussels and abalones [9-12]. However, little information is available on the genetic diversity of the genus Meretrix based on microsatellite markers, because these useful markers have only recently been applied to the genus.

Microsatellites, also known as single sequence repeats (SSRs), are highly useful because of their abundance, even distribution of short lengths and high polymorphism. Although high-throughput sequencing, called next-generation sequencing (NGS), techniques have been applied to recent MS marker development $[13,14]$, the development of effective MS markers is tedious, labor-intensive and expensive, involving the screening of genomic libraries using repetitive probes and sequencing of positive clones [15]. One way to solve this problem is to apply MS markers developed for a particular species to closely related species, which has been proven useful in fishes [16,17]. In this study, we developed microsatellite markers for $M$. petechialis and tested their transferability to other clams belonging to the order Veneroida.

\section{Results}

\subsection{Microsatellite Marker Isolation and Polymorphism Analyses}

In total, 1,700 positive colonies were obtained from the transformation of the hard clam $(\mathrm{GT})_{n}$-enriched genomic DNA library. Of these, 1000 clones were randomly picked and sequenced. Primers were designed and tested for 160 loci that contained a minimum of eight repeat units, and only 50 primer sets produced strongly amplified PCR products. Of those, 35 gave either inconsistent or noise peaks, despite adjusting the dNTP concentration and PCR annealing temperature. The remaining 15 were considered successful genetic markers. Table 1 lists the variability information and GenBank accession numbers of the 15 microsatellite markers. Among these, nine showing polymorphisms in the amplified microsatellite markers were used for further genetic study of two hard clam populations.

\subsection{Genetic Variability of Meretrix petechialis Populations}

Table 2 summarizes the genetic characterization indices estimated for the two hard clam populations. The mean allelic richness per locus ranged from 2.0 to 16.3 in the two populations. The average number of alleles in all populations was 6.0. No linkage disequilibrium was found between any pair of loci $(p>0.05)$, indicating that the markers were independent. The Hardy-Weinberg equilibrium (HWE) test, indicating the deviation from expected heterozygosity, showed significant deviation after sequential Bonferroni correction $(p<0.01)$ in the Mp07-nfrdi locus with excess heterozygosity in two populations. No null alleles and no genetic differentiation between GC and MA populations were detected by $F_{\mathrm{ST}}(=0.013, p<0.01)$ using all nine microsatellite markers.

\subsection{Cross-Species Amplification}

Cross-species amplification of 15 loci was conducted in 12 related species belonging to four families in the order Veneroida (Bivalvia: Heteroconchia). The 12 species were representative of shellfish. As shown in Table 3, two MS markers, Mp04-nfrdi and Mp09-nfrdi, produced PCR products from only $M$. petechialis. No PCR product was obtained from the remaining 11 tested species. In 
contrast, the marker Mp06-nfrdi produced PCR products from 11 of the 12 tested species, followed by the Mp02-nfrdi and Mp08-nfrdi, which produced PCR products from 10 of the 12 species. These markers were polymorphic in the 5,6, and 7 species, respectively. The transferability of 15 loci to the 12 related species ranged from $33.3 \%$ to $66.7 \%$, with the ratio of polymorphic sites being $6.7 \%-46.7 \%$. However, some of the markers that were monomorphic in M. petechialis were polymorphic in other species, and vice versa.

\section{Discussion}

In total, 15 microsatellite markers were obtained from a partial genomic library of $M$. petechialis enriched in GT repeats. Nine were polymorphic, with an average allele number of six, and six were monomorphic in 95 tested individuals. Deviation from HWE equilibrium, including significant deviation in the Mp07-nfrdi locus, indicated excess heterozygosity in two populations. Deviations from HWE have been observed in several marine commercial fish [18] and mollusks [19-22]. Deviation from HWE may be due to one or a combination of factors, including the substructure of samples due to the pooling of samples from many sites, inbreeding or the presence of null alleles [23]. The presence of null alleles produce an excess of homozygotes, and heterozygote deficiency observed in several bivalves, including the geoduck clam, European flat oyster [24] and pink mucket [25], is thought to be due to the presence of null alleles [26]. We did not find any null alleles among the 15 loci tested in M. petechialis, which may be one reason for the excess of heterozygosity. This is a major limitation in cross-species transfer of microsatellite markers [27].

The other possible reason of the excess of heterozygosity can be a genetic bottleneck caused by a recent decrease of the population due to ocean pollution and reclamation, such as the reclamation of the Saemangeum area, the most productive site of M. petechialis in the country [5]. A population that suffered a recent bottleneck can show an excess of heterozygosity, because alleles are generally lost faster than heterozygosity during a bottleneck [28,29].

Type-specific microsatellite markers, such as Mp04-nfrdi and Mp09-nfrdi, can be useful for species identification, especially at the early larval stage when morphological distinction between these two species is impossible. Torii et al. [30] reported that the two species could be differentiated with $98.89 \%$ success by modified discrimination scores using five characteristics. They also showed that the matching scores of nucleotide sequences between the two species were $93 \%$ and $97 \%$ in the mitochondrial COI gene and ITS-1 gene, respectively. However, these methods can be applied only to individuals of sufficient size, require time-consuming sequencing procedures and cannot be used on mixed larval samples to detect the presence of specific species. Restriction analysis of specific PCR products can be used to produce specific banding patterns, which can be used for certain purposes, such as the identification of the M. petechialis-M. lusoria hybrid [31]; however, these techniques cannot be used in mixed samples. Species-specific microsatellite markers have been used to identify specific oyster species in mixtures of oyster larvae [32]. As with other aquatic animals, microsatellite markers have been used to determine parentage in the genus Meretrix, either alone [33] or in combination with other genetic markers [34]. The possible use of the two species-specific loci for species identification was further confirmed by a BLAST search of primer sequences, which showed no match to known DNA sequences. 
Nuclear microsatellite markers are the most popular genetic markers in population genetic studies, but they need to be developed and optimized for each species, which is time-consuming and somewhat expensive. Thus, markers that can be readily transferred to related species are desirable. We tested the transferability of 15 microsatellite makers developed in M. petechialis against 12 species in four families of the order Veneroida. As shown in Table 3, the overall cross-species transferability of the 15 makers to the 12 tested species ranged from $33.3 \%$ to $66.7 \%$, with polymorphic loci ranging from 13.3\% to 46.7\%. Among the 15 markers, three loci, Mp02-nfrdi, Mp06-nfrdi and Mp08-nfrdi, showed an amplification success rate of $90.9 \%$, with a polymorphism ratio of $45.5 \%-63.6 \%$, suggesting that these markers can be used as universal markers in related species. In the cross species PCR, some of the products in other species were far outside the range of those observed in M. petechialis. For example, MP05 has a size range of 78-92 in 95 specimens of M. petechialis, but a range of 82-332 in only two specimens of Cyclina sinensis. Therefore, further cloning and sequence analysis of these PCR products might be necessary for the confirmation of these PCR products as real alleles. The limited information available regarding cross-species transfer of microsatellite markers developed in bivalves shows the transferability between species within genera to be $93.3 \%$ (14 of 15) in Crassostrea [35] and 86.7\% (13 of 15) in Lampsilis [25].

As Barbará et al. [27] suggested, the evolutionary distance between the source of microsatellite markers and the target species is the most important factor affecting the success of cross-species amplification. This was confirmed in our study, as shown in Figure 1. Except for the Psammobiidae with one member, transferability was related to the evolutionary distance deduced from the sequence of $16 \mathrm{~S}$ rRNA, averaging $56.6 \%, 44.4 \%$ and $40 \%$ for Veneridae, Mactridae and Corbiculidae, respectively. One exceptional case in our study was the low transferability to M. lusoria, the most related species, which showed successful amplification at only seven loci. One possible reason could be the genetic homogeneity of the individuals used for the test, but no information regarding the genetic diversity of this species in the Korean Peninsula is available. In an analysis of 611 cross-species microsatellite marker transfers, Barbará et al. [27] reported that the percentage of amplified markers among families within the order ranged from $28 \%$ to $33 \%$. The transferability of the microsatellite markers developed in our study has a comparably high transferability, and some, such as those listed above, could be used as universal markers in the order Veneroida. 
Table 1. Characteristics of 15 microsatellite loci isolated from Meretrix petechiails.

\begin{tabular}{|c|c|c|c|c|c|c|c|c|c|}
\hline Primer name & Core sequence & & Primer $\left(5^{\prime} \rightarrow 3^{\prime}\right)$ & Annealing temp. & Amplicon size & No. Allele & Ho & $\mathrm{He}$ & GenBank accession No. \\
\hline Mp01-nfrdi & $(\mathrm{AC})_{34}$ & $\begin{array}{l}\mathbf{F} \\
\mathbf{R}\end{array}$ & $\begin{array}{l}\text { GACCGCGATCGTATACAAGTCCC } \\
\text { TCCGTGCATGTGTGCCTATATCC }\end{array}$ & 48 & 179-199 & 4 & 0.372 & 0.306 & JX017338 \\
\hline Mp02-nfrdi & $(\mathrm{AC})_{14}$ & $\begin{array}{l}\mathbf{F} \\
\mathbf{R}\end{array}$ & $\begin{array}{l}\text { CATGGGAAGCAGGCGGTTTGTTG } \\
\text { ACATACGTGTGCGCATGCGTGTG }\end{array}$ & 52 & $102-164$ & 9 & 0.327 & 0.287 & JX017339 \\
\hline Mp03-nfrdi & $(\mathrm{AC})_{29}$ & $\begin{array}{l}\mathbf{F} \\
\mathbf{R}\end{array}$ & $\begin{array}{l}\text { TCGTATACAAGTCCCGGTCCTGG } \\
\text { TCCGTGCATGTGTGCCTATATCC }\end{array}$ & 50 & $149-155$ & 2 & 0.118 & 0.111 & JX017340 \\
\hline Mp04-nfrdi & $(\mathrm{AC})_{24}$ & $\begin{array}{l}\mathbf{F} \\
\mathbf{R}\end{array}$ & $\begin{array}{l}\text { GGATTCCAGTTTAGCCCTCTC } \\
\text { TATACACAGCGCAAGGTGAAC }\end{array}$ & 52 & $246-286$ & 13 & 0.244 & 0.218 & JX017341 \\
\hline Mp05-nfrdi & $(\mathrm{AC})_{28}$ & $\begin{array}{l}\mathbf{F} \\
\mathbf{R}\end{array}$ & $\begin{array}{l}\text { CCATATTTGACAGCAGTTTCGTC } \\
\text { CAAAGTATCGCCTGAACCTGAC }\end{array}$ & 50 & $78-92$ & 6 & 0.369 & 0.34 & JX017342 \\
\hline Mp06-nfrdi & $(\mathrm{AC})_{11}$ & $\begin{array}{l}\mathbf{F} \\
\mathbf{R}\end{array}$ & $\begin{array}{l}\text { ACAGGACCTGATCGTGAACAC } \\
\text { CAGGCCGAGTGCAGAAGTGGA }\end{array}$ & 50 & $168-196$ & 2 & 0.14 & 0.13 & JX017343 \\
\hline Mp07-nfrdi & $(\mathrm{AC})_{31}$ & $\begin{array}{l}\mathbf{F} \\
\mathbf{R}\end{array}$ & $\begin{array}{l}\text { GTATACAAGTCCCGGTCCTGT } \\
\text { CATCCGTGCATGTGTGCCTAT }\end{array}$ & 48 & $103-173$ & 5 & 0.675 & 0.455 & JX017344 \\
\hline Mp08-nfrdi & $(\mathrm{AC})_{37}$ & $\begin{array}{l}\mathbf{F} \\
\mathbf{R}\end{array}$ & $\begin{array}{l}\text { TATAGTTCGGACGGACATGGACA } \\
\text { GCCCAAGAGTTGAACATCAGGTT }\end{array}$ & 48 & $129-227$ & 43 & 0.603 & 0.594 & JX017345 \\
\hline Mp09-nfrdi & $\begin{array}{l}(\mathrm{GT})_{5} \mathrm{CT}(\mathrm{GT})_{7} \\
\mathrm{CT}(\mathrm{GT})_{3}\end{array}$ & $\begin{array}{l}\mathbf{F} \\
\mathbf{R}\end{array}$ & $\begin{array}{l}\text { ACATACGTGTGCGCATGCATGTG } \\
\text { GCAGGCGGTTTGGCTGGCAGGTC }\end{array}$ & 58 & $209-267$ & 6 & 0.394 & 0.381 & JX017346 \\
\hline Mp10-nfrdi & $(\mathrm{AC})_{10}$ & $\begin{array}{l}\mathbf{F} \\
\mathbf{R}\end{array}$ & $\begin{array}{l}\text { AGGACCTGATCCTGAACACAC } \\
\text { TCTGCATGACTGTCTGTCTCC }\end{array}$ & 48 & 188 & 1 & - & - & JX017347 \\
\hline Mp11-nfrdi & $(\mathrm{GT})_{11}$ & $\begin{array}{l}\mathbf{F} \\
\mathbf{R}\end{array}$ & $\begin{array}{l}\text { CCGAGTGCAGAAGAGGAACACAC } \\
\text { CACACAGGACCTGATCGTGAACA }\end{array}$ & 48 & 118 & 1 & - & - & JX017348 \\
\hline Mp12-nfrdi & $(\mathrm{AC})_{35}$ & $\begin{array}{l}\mathbf{F} \\
\mathbf{R}\end{array}$ & $\begin{array}{l}\text { ACAGACCAAACCATCCTTATCCC } \\
\text { CTATTTTCAAGCCAGGCAGAATG }\end{array}$ & 50 & 93 & 1 & - & - & JX017349 \\
\hline Mp13-nfrdi & $(\mathrm{AC})_{8}$ & $\begin{array}{l}\mathbf{F} \\
\mathbf{R}\end{array}$ & $\begin{array}{l}\text { TTAACCCGGCCACCCACCTATAC } \\
\text { CGTATTTGTGCGCATGCGTGTGC }\end{array}$ & 50 & 83 & 1 & - & - & JX017350 \\
\hline Mp14-nfrdi & $(\mathrm{GT})_{10}$ & $\begin{array}{l}\mathbf{F} \\
\mathbf{R}\end{array}$ & $\begin{array}{l}\text { GCAGCAGGCCGAGTGCAGAAG } \\
\text { CGTTGGGGCACCGCGACCACA }\end{array}$ & 48 & 165 & 1 & - & - & JX017351 \\
\hline Mp15-nfrdi & $\begin{array}{c}(\mathrm{GT})_{11} \mathrm{TT}(\mathrm{GT})_{16} \\
(\mathrm{AT})_{2}(\mathrm{GT})_{2} \mathrm{GA}(\mathrm{GT})_{9}\end{array}$ & $\begin{array}{l}\mathbf{F} \\
\mathbf{R}\end{array}$ & $\begin{array}{l}\text { GCCTATATCTGCGTATGTGCATC } \\
\text { AGGGGACCGCGATCGTATACAAG }\end{array}$ & 48 & 112 & 1 & - & - & JX017352 \\
\hline
\end{tabular}


Table 2. Variability of alleles at nine microsatellite loci in two populations of Meretrix petechialis from Korea.

\begin{tabular}{|c|c|c|c|c|c|c|c|c|c|c|c|}
\hline \multirow[b]{2}{*}{ Pop. } & & \multicolumn{9}{|c|}{ Microsatellite loci } & \multirow{2}{*}{ Means } \\
\hline & & Mp01-nfrdi & Mp02-nfrdi & Mp03-nfrdi & Mp04-nfrdi & Mp05-nfrdi & Mp06-nfrdi & Mp07-nfrdi & Mp08-nfrdi & Mp09-nfrdi & \\
\hline \multirow{7}{*}{$\mathrm{GC}$} & $N$ & 35 & 35 & 35 & 34 & 33 & 35 & 35 & 35 & 35 & 34.7 \\
\hline & $\mathrm{Na}$ & 3 & 5 & 2 & 7 & 2 & 2 & 2 & 18 & 3 & 5.3 \\
\hline & $A_{\mathrm{R}}$ & 2.8 & 4.6 & 2.0 & 6.5 & 2.0 & 2.0 & 2.0 & 15.7 & 2.8 & 4.9 \\
\hline & $R$ & 179-199 & $102-136$ & $149-155$ & $246-286$ & $78-92$ & $168-196$ & $143-173$ & $129-205$ & $209-247$ & \\
\hline & Ho & 0.400 & 0.286 & 0.114 & 0.353 & 0.303 & 0.057 & 0.714 & 0.543 & 0.571 & 0.372 \\
\hline & $\mathrm{He}$ & 0.330 & 0.260 & 0.109 & 0.319 & 0.261 & 0.056 & 0.466 & 0.549 & 0.467 & 0.365 \\
\hline & FIS & -0.212 & -0.097 & -0.045 & -0.107 & -0.161 & -0.015 & $-0.533 *$ & 0.011 & -0.224 & -0.084 \\
\hline \multirow{7}{*}{ MA } & $N$ & 58 & 57 & 58 & 58 & 58 & 58 & 58 & 58 & 57 & 57.8 \\
\hline & $\mathrm{Na}$ & 2 & 6 & 2 & 8 & 2 & 2 & 3 & 26 & 4 & 6.7 \\
\hline & $A_{\mathrm{R}}$ & 2.0 & 4.9 & 2.0 & 5.5 & 2.0 & 2.0 & 2.5 & 16.9 & 3.0 & 5.2 \\
\hline & $R$ & 179-199 & $102-164$ & $149-155$ & $246-280$ & $78-92$ & $168-196$ & $103-173$ & $129-227$ & $209-267$ & \\
\hline & $H_{\mathrm{o}}$ & 0.431 & 0.263 & 0.138 & 0.345 & 0.379 & 0.155 & 0.603 & 0.586 & 0.333 & 0.355 \\
\hline & $\mathrm{He}$ & 0.341 & 0.243 & 0.130 & 0.308 & 0.331 & 0.144 & 0.430 & 0.651 & 0.309 & 0.374 \\
\hline & FIS & -0.264 & -0.084 & -0.065 & -0.119 & -0.146 & -0.075 & $-0.403 *$ & 0.099 & -0.078 & -0.051 \\
\hline \multirow{7}{*}{$\begin{array}{c}\text { Mean } \\
\text { all pops. }\end{array}$} & $N$ & 46.5 & 46 & 46.5 & 46 & 45.5 & 46.5 & 46.5 & 46.5 & 46 & \\
\hline & $\mathrm{Na}$ & 2.5 & 5.5 & 2 & 7.5 & 2 & 2 & 2.5 & 22 & 3.5 & \\
\hline & $A_{\mathrm{R}}$ & 2.4 & 4.8 & 2 & 6 & 2 & 1.9914 & 2.3 & 16.3 & 2.9 & \\
\hline & $R$ & 179-199 & $102-164$ & $149-155$ & $246-286$ & $78-92$ & $168-196$ & $103-173$ & $129-227$ & $209-267$ & \\
\hline & $H_{\mathrm{o}}$ & 0.386 & 0.275 & 0.126 & 0.349 & 0.341 & 0.106 & 0.659 & 0.565 & 0.452 & \\
\hline & $\mathrm{He}$ & 0.336 & 0.252 & 0.119 & 0.314 & 0.296 & 0.1 & 0.448 & 0.6 & 0.388 & \\
\hline & FIS & -0.238 & -0.091 & -0.055 & -0.113 & -0.154 & -0.045 & $-0.468 *$ & -0.055 & -0.151 & \\
\hline
\end{tabular}

Number of samples $(N)$; number of alleles per locus $(\mathrm{Na})$; allelic richness $\left(A_{\mathrm{R}}\right)$; allelic size range $(R)$; expected heterozygotity $(H \mathrm{e})$; and observed heterozygosity $(H \mathrm{o})$ are given for each population and locus. ${ }^{*}$ Not in conformity with Hardy-Weinberg equilibrium $(p<0.01$, Bonferroni-corrected value). 
Table 3. Allele sizes in cross-species amplification of 15 microsatellite loci of Meretrix petechiails in 12 related species.

\begin{tabular}{|c|c|c|c|c|c|c|c|c|c|c|c|c|c|c|}
\hline \multirow{2}{*}{$\begin{array}{c}\text { Taxonomy } \\
\text { Species }\end{array}$} & \multirow[b]{2}{*}{$\begin{array}{c}\text { Meretrix } \\
\text { petechialis }\end{array}$} & \multirow[b]{2}{*}{$\begin{array}{l}\text { Meretrix } \\
\text { lousoria }\end{array}$} & \multicolumn{2}{|c|}{ Veneridae } & \multirow[b]{2}{*}{$\begin{array}{c}\text { Ruditapes } \\
\text { philippinarum }\end{array}$} & \multirow{2}{*}{$\begin{array}{c}\text { Psammobiidae } \\
\text { Nuttallia } \\
\text { japonica }\end{array}$} & \multirow[b]{2}{*}{$\begin{array}{l}\text { Mactra } \\
\text { chinensis }\end{array}$} & \multirow{2}{*}{$\begin{array}{c}\text { Mactridae } \\
\text { Mactra } \\
\text { veneriformis }\end{array}$} & \multirow[b]{2}{*}{$\begin{array}{l}\text { Tresus } \\
\text { keenae }\end{array}$} & \multirow[b]{2}{*}{$\begin{array}{l}\text { Corbicula } \\
\text { japonica }\end{array}$} & \multicolumn{2}{|c|}{ Corbiculidae } & \multirow[b]{2}{*}{$\begin{array}{c}\text { Corbicula } \\
\text { colorata }\end{array}$} & \multirow[b]{2}{*}{ Transferability * } \\
\hline & & & $\begin{array}{c}\text { Gomphina } \\
\text { veneriformis }\end{array}$ & $\begin{array}{l}\text { Cyclina } \\
\text { sinensis }\end{array}$ & & & & & & & $\begin{array}{c}\text { Corbicula } \\
\text { leana }\end{array}$ & $\begin{array}{r}\text { Corbicula } \\
\text { fluminea }\end{array}$ & & \\
\hline $\begin{array}{l}\text { Number of } \\
\text { Individuals }\end{array}$ & 95 & 7 & 2 & 2 & 9 & 3 & 1 & 2 & 1 & 2 & 2 & 4 & 2 & \\
\hline Mp01-nfrdi & 179-199 & 179 & - & $91-139$ & - & $179-199$ & - & - & - & - & 77 & - & 83 & $41.7(16.7)$ \\
\hline Mp02-nfrdi & $102-164$ & - & 132 & $64-124$ & $112-306$ & 222 & - & 146 & $146-150$ & $276-334$ & $242-300$ & $82-178$ & 82 & $83.3(50.0)$ \\
\hline Mp03-nfrdi & $149-155$ & 149 & - & 143 & 117 & - & - & 65 & - & - & - & - & - & $33.3(0)$ \\
\hline Mp04-nfrdi & $246-286$ & - & - & - & - & - & - & - & - & - & - & - & - & $0 / 0$ \\
\hline Mp05-nfrdi & $78-92$ & $78-92$ & - & $82-332$ & - & 112 & - & 214 & - & 108 & - & 96 & - & $50.0(16.7)$ \\
\hline Mp06-nfrdi & $168-196$ & 168 & $126-296$ & $126-298$ & $72-122$ & $126-140$ & 196 & $82-228$ & 164 & 98 & 166 & - & 132 & $91.7(33.3)$ \\
\hline Mp07-nfrdi & $103-173$ & $143-173$ & - & $91-111$ & - & 67 & - & - & - & - & $155-175$ & - & 93 & $41.7(25.0)$ \\
\hline Mp08-nfrdi & $129-227$ & - & $87-123$ & 89-99 & $137-245$ & $159-161$ & $169-253$ & - & 215 & 101 & $243-245$ & $111-135$ & 245 & $83.3(58.3)$ \\
\hline Mp09-nfrdi & 209-267 & - & - & - & - & - & - & - & - & - & - & - & - & $0 / 0$ \\
\hline Mp10-nfrdi & 188 & 188 & 196 & $192-198$ & $94-108$ & - & $110-178$ & 182 & 112 & $266-270$ & - & $100-166$ & - & $75.0(41.7)$ \\
\hline Mp11-nfrdi & 118 & - & $132-138$ & - & - & $132-146$ & 156 & - & 94-178 & - & - & - & 138 & $41.7(25.0)$ \\
\hline Mp12-nfrdi & 93 & - & $65-111$ & 93 & $95-123$ & - & - & $121-161$ & - & - & - & - & - & $33.3(25.0)$ \\
\hline Mp13-nfrdi & 83 & - & 71 & - & $65-87$ & $115-215$ & $91-219$ & 91-139 & 199 & - & 105 & 83 & - & $66.7(33.3)$ \\
\hline Mp14-nfrdi & 165 & - & 157 & 157 & $129-131$ & 75 & - & 101 & - & - & - & - & $239-243$ & $50.0(16.7)$ \\
\hline Mp15-nfrdi & 112 & $76-112$ & - & - & 102 & - & - & 222 & - & - & - & $126-350$ & - & $33.3(16.7)$ \\
\hline Transferability * & - & $\begin{array}{l}46.7 \\
(20.0)\end{array}$ & $\begin{array}{l}53.0 \\
(26.7)\end{array}$ & $\begin{array}{c}66.7 \\
(40.0)\end{array}$ & $\begin{array}{c}60 \\
(46.7)\end{array}$ & $\begin{array}{l}60.0 \\
(33.3)\end{array}$ & $\begin{array}{l}33.3 \\
(20.0)\end{array}$ & $\begin{array}{c}60.0 \\
(20.0)\end{array}$ & $\begin{array}{l}40.0 \\
(13.3)\end{array}$ & $\begin{array}{l}33.3 \\
(13.3)\end{array}$ & $\begin{array}{l}40.0 \\
(20.0)\end{array}$ & $\begin{array}{l}40.0 \\
(26.7)\end{array}$ & $\begin{array}{l}46.7 \\
(6.7)\end{array}$ & \\
\hline
\end{tabular}


Figure 1. Neighber-Joining tree based on the 16S rRNA sequences. The 16S rRNA sequence for Corbicula colorata (JX399588), Corbicula leana (JX399587), Tresus keenae (JX399585) and Gomphin veneriformis (JX399586) was determined in this study. The Genbank accession numbers for rest of the samples are Ruditapes philippinarum (JN969951.1), Meretrix petechialis (NC012767.1), Meretrix lusoria (JN969940.1), Cyclina sinensis (DQ356379.1), Corbicula japonica (AB304507.1), Corbicula fluminea (DQ280039.1), Nuttallia japonica (AB476426.1), Mactra chinensis (JN674598.1). Numbers near the node indicate boostrap support.

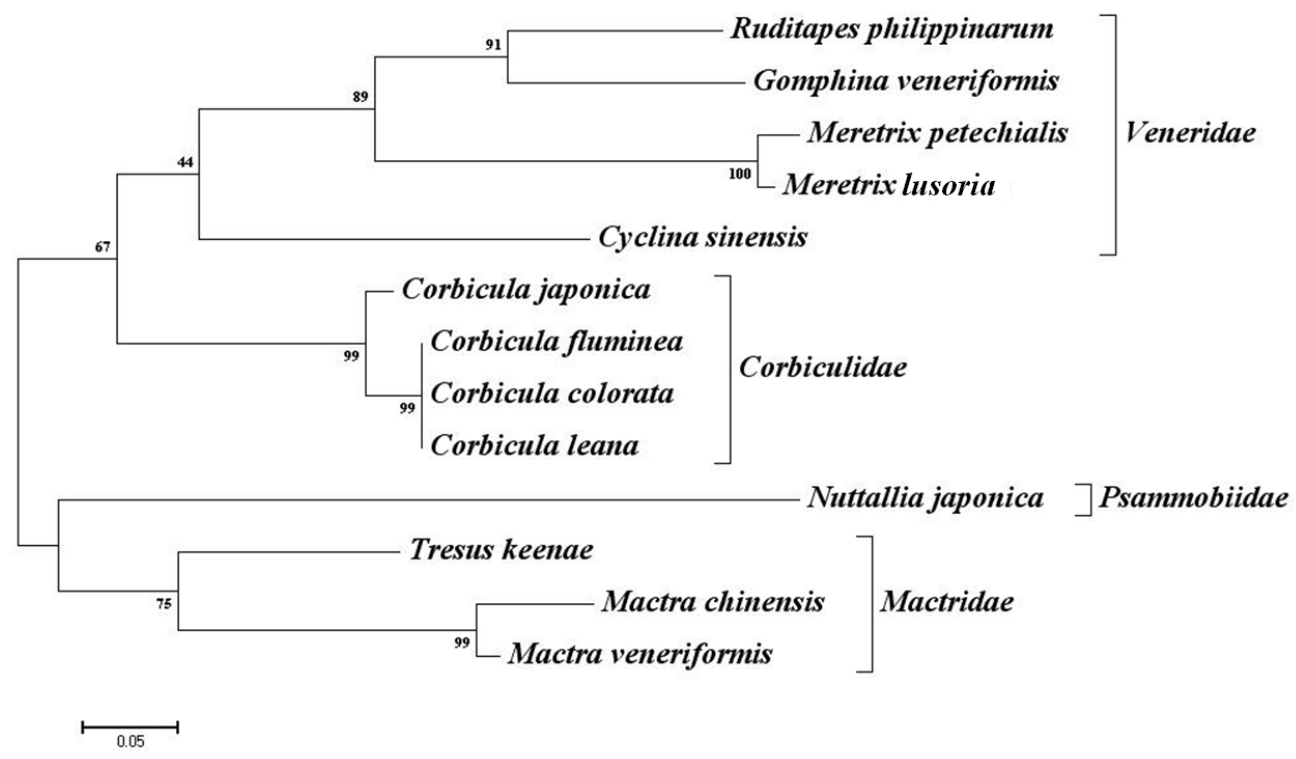

\section{Experimental Section}

\subsection{Sample Collection}

A total of 95 wild hard-clam samples were collected from two locations on the west coast of the Korean Peninsula, Gochang (GC, $N=35)$ and Muan (MA, $N=60$ ). Tissue samples from a leg were preserved in $100 \%$ ethanol at the sampling site and then transported to the laboratory for DNA extraction. Total DNA was isolated from each sample using a MagExtractor MFX-6100 automated DNA extraction system (Toyobo, Osaka, Japan). The extracted genomic DNA was quantified using a Nanodrop ND-1000 spectrophotometer (Thermo Fisher Scientific, Barrington, IL, USA) and stored at $-20{ }^{\circ} \mathrm{C}$ until microsatellite genotyping analysis. For the cross-species transferability test, DNA was extracted by the same method from ethanol-fixed tissues of 12 related species belonging to four families of the order Veneroida that had been stored at the National Fisheries Research and Development Institute, Busan.

\subsection{Library Construction and Sequencing}

A partial genomic library enriched in GT repeats was constructed using the procedures described by Hamilton et al. [15]. Genomic DNA was isolated from one individual using the TNES-urea buffer method [36]. Extracted DNA was digested with a restriction enzyme mixture containing AluI, RsaI, NheI and HhaI (New England Biolabs, Beverly, MA, USA). Following agarose gel electrophoresis, 
DNA fragments of 200-800 base pairs (bp) were isolated from the gel and ligated to an adapter SNX/SNX rev linker [15]. The linker-ligated DNA was amplified using SNX as a linker-specific primer for polymerase chain reaction (PCR). For enrichment, the DNA was denatured, hybridized to biotin-labeled repeat sequence $(\mathrm{GT})_{10}$ probes and then attached to streptavidin-coated magnetic beads (Promega, Madison, WI, USA). The enriched fragments were digested with the enzyme NheI, and ligated into the XbaI-digested pUC18 vector (Pharmacia, Piscataway, NJ, USA), followed by transformation into Escherichia coli DH5a-competent cells. The positive colonies were screened for the presence of a repeat insert using PCR with universal M13 primers and non-biotin-labeled dinucleotide primers. PCR products were examined on $2 \%$ agarose gels, and inserts producing two or more bands were considered to contain a microsatellite locus. Positive clones were cultured, and plasmids from insert-containing colonies were recovered using the QIAprep Spin Miniprep Kit (Qiagen) and sequenced using the BigDye Terminator Cycle Sequencing Ready Reaction Kit (ver. 3.1; Applied Biosystems, Foster City, CA, USA) and an automated sequencer (ABI Prism 310 Genetic Analyzer; Applied Biosystems).

\subsection{Primer Design and Genotyping}

Primers were designed based on sequences flanking the microsatellite motifs using the PRIMER 3 software package. Newly designed PCR primer pairs were tested to optimize annealing temperatures: a gradient PCR at $50-60{ }^{\circ} \mathrm{C}$ annealing temperature range was performed on a set of samples from eight individuals. PCR amplification was performed in a $10 \mu \mathrm{L}$ reaction mixture containing $0.25 \mathrm{U}$ Extaq DNA polymerase (TaKaRa Biomedical Inc., Shiga, Japan), $1 \times$ PCR buffer, $0.2 \mathrm{mM}$ dNTP mix, 10 pmol each primer (forward primer of each pair was 5'-end-labeled with 6-FAM, NED and HEX dyes; PE Applied Biosystems) and 100 ng template DNA, using a PTC 200 DNA Engine (MJ Research, Waltham, MA, USA). PCR conditions were as follows: $11 \mathrm{~min}$ at $95{ }^{\circ} \mathrm{C}$, followed by 35 cycles of $1 \mathrm{~min}$ at $94{ }^{\circ} \mathrm{C}, 1 \mathrm{~min}$ at the annealing temperature listed in Table 2, and $1 \mathrm{~min}$ at $72{ }^{\circ} \mathrm{C}$, with a final extension of $5 \mathrm{~min}$ at $72{ }^{\circ} \mathrm{C}$. Microsatellite polymorphisms were screened using an ABI PRISM 3130 XL automated DNA sequencer (Applied Biosystems), and alleles were designated according to PCR product size, relative to a molecular size marker (GENESCAN 400 HD [ROX]; PE Applied Biosystems). Fluorescent DNA fragments were analyzed using GENESCAN.

\subsection{Statistical Analysis}

The number of alleles per locus, allele frequency and heterozygosity were calculated using CERVUS 3.03 [37]. Tests for population-wide linkage disequilibrium between pairs of loci and deviations from HWE were estimated using GENEPOP ver.4.0 [38], and the adjusted $P$-values for both analyses were obtained using a sequential Bonferroni test for multiple comparisons [39]. MICRO-CHECKER 2.2.3 [40] was used to test for the presence of null alleles. Allelic richness $\left(A_{\mathrm{R}}\right)$ as a standardized measure of the number of alleles per locus, independent of the sample size, was calculated using FSTAT version 2.9.3 [41]. 


\section{Conclusions}

To our knowledge, this is the first report on the development of microsatellite markers for M. petechialis. As the aquaculture of this species is at an early stage, this study will be helpful in the future genetic improvement of culture stocks and in managing the natural resource of this economically valuable, but threatened, species. In addition, some of the microsatellite markers could be used as universal genetic markers for other species.

\section{Acknowledgments}

This work was supported by grants from the National Fisheries Research and Development Institute (NFRDI) in Korea.

\section{References}

1. Yamakawa, Y.A.; Yamaguchi, M.; Imai, H. Genetic relationships among species of Meretrix (Mollusca: Veneridae) in the Western Pacific Ocean. Pac. Sci. 2008, 62, 385-394.

2. Yoosukh, W.; Matsukuma, A. Taxonomic study on Meretrix (Mollusca: Bivalvia) from Thailand. Phuket. Mar. Biol. Cent. Spec. Publ. 2001, 25, 451-460.

3. Henmi, Y. Hamaguri no Seibutsugaku. In Higo hamaguri no shigen kanri to burando ka; Uchino, A., Ed.; Kumamoto daigaku seisouken sosho 6. Seibundo: Tokyo, Japan, 2009; pp. 81-121.

4. Yamashita, Y.; Satoh, S.; Kim, K.; Henmi, Y.; Nagata, H.; Yamamoto, S.; Ikeguchi, A.; Mizuma, Y.; Nawa, J.; Takashima, U. Silent tidal flat: Current situations of Meretrix spp. in the coastal area of Japan and Korea. Rep. Takagi Fund Citiz. Sci. 2004, 1, 85-91.

5. Hong, J.S.; Yamashita, H.; Sato, S. The Saemangeum reclamation project in South Korea threatens to collapse a unique mollusk, ectosymbiotic bivalve species attached to the shell of Lingula anatina. Plankton Benthos Res. 2007, 2, 70-75.

6. Wolstenholme, D.R. Animal mitochondrial DNA: Structure and evolution. Int. Rev. Cytol. 1992, $141,173-216$.

7. Passamonti, M.; Scali, V. Gender associated mitochondrial DNA heteroplasmy in the venerid clam Tapes philippinarum (Mollusca: Bivalvia). Curr. Genet. 2001, 39, 117-124.

8. Breton, S.; Doucet-Beaupré, H.D.; Stewart, D.T.; Hoeh, W.R.; Blier, P.U. The unusual system of doubly uniparental inheritance of mtDNA: Isn't one enough? Trends Genet. 2007, 23, 465-474.

9. Bierne, N.; Launey, S.; Naciri-Graven, Y.; Bonhomme, F. Early effect of inbreeding as revealed by microsatellite analyses on Ostrea edulis larvae. Genetics 1998, 148, 1893-1906.

10. Holland, B.S. Invasion without a bottleneck: Microsatellite variation in natural and invasive populations of the brown mussel Perna perna (L). Mar. Biotechnol. 2001, 3, 407-415.

11. Selvamani, M.J.P.; Degnan, S.M.; Paetkau, D.; Degnan, B.M. Highly polymorphic microsatellite loci in the Heron Reef population of the tropical abalone Haliotis asinina. Mol. Ecol. 2000, 9 , 1184-1186.

12. Li Q.; Park, C.; Kobayashi, T.; Kijima, A. Inheritance of microsatellite DNA markers in the Pacific abalone Haliotis discus hannai. Mar. Biotechnol. 2003, 5, 331-338. 
13. Abdelkrim, J.; Robertson, B.C.; Stanton, J.-A.L.; Gemmell, N.J. Fast, cost effective development of species-specific microsatellite markers by genomic sequencing. BioTechniques 2009, 46, 185-191.

14. Kang, J.H.; Park, J.Y.; Jo, H.S. Rapid Development of microsatellite markers with 454 pyrosequencing in a vulnerable fish, the mottled skate, Raja pulchra. Int. J. Mol. Sci. 2012, 13, 7199-7211.

15. Hamilton, M.; Pincus, E.L.; di Fiore, A.; Fleischer, R.C. Universal linker and ligation procedures for construction of genomic DNA libraries enriched for microsatellites. Biotechniques 1999, 27, 500-507.

16. Liu, Z.; Tan, G.; Kucuktas, H.; Li., P.; Karsi, A.; Yant, D.R.; Dunham, R.A. High levels of conservation at microsatellite loci among Ictalurid catfishes. J. Hered. 1999, 90, 307-312.

17. Wu, L.; Kaufman, L.; Fuerst, P.A. Isolation of microsatellite markers in Astatoreochromis alluaudi and their cross-species amplifications in other African cichlids. Mol. Ecol. 1999, 8, 895-897.

18. Kuang, Y.Y.; Tong, G.X.; Xu, W.; Yin, J.S.; Sun, X.W. Analysis of genetic diversity in the endangered Hucho taimen from China. Acta Ecol. Sin. 2009, 29, 92-97.

19. Sekino, M.; Hara, M. Microsatellite DNA loci in Pacic abalone Haliotis discus discus (Mollusca, Gastropoda, Haliotidae). Mol. Ecol. Notes 2001, 1, 8-10.

20. Hedgecock, D.; Li, G.; Hubert, S.; Bucklin, K.; Ribes, V. Widespread null alleles and poor cross-species amplification of microsatellite DNA loci cloned from the Pacific oyster, Crassostrea gigas. J. Shellfish Res. 2004, 23, 379-385.

21. Li, Q.; Yu, H.; Yu, R.H. Genetic variability assessed by microsatellites in cultured populations of the Pacific oyster (Crassostrea gigas) in China. Aquaculture 2006, 259, 95-102.

22. Panova, M.; Mäkinen, T.; Fokin, M.; André, C.; Johannesson, K. Microsatellite cross species amplification in the genus Littorina and detection of null alleles in Littorina saxatilis. J. Molluscan Stud. 2008, 74, 111-117.

23. Zouros, E.; Foltz, D.W. Possible explanations of heterozygote deficiency in bivalve mollusks. Malacologia 1984, 25, 583-591.

24. Launey, S.; Ledu, C.; Boudry, P.; Bonhomme, F.; Naciri-Graven, Y. Geographic structure in the European flat oyster (Ostrea edulis L.) as revealed by microsatellite polymorphism. J. Hered. 2002, 93, 331-338.

25. Eackles, M.S.; King, T.L. Isolation and characterization of microsatellite loci in Lampsilis abrupta (Bivalvia: Unionidae) and cross-species amplification within the genus. Mol. Ecol. Notes 2002, 2, 559-562.

26. Vadopalas, B.; Leclair, L.L.; Bentzen, P. Microsatellite and allozyme analyses reveal few genetic differences among spatially distinct aggregations of geoduck clam (Panopea abrupta, Conrad 1849). J. Shellfish Res. 2004, 23, 693-706.

27. Barbará, T.; Palma-Silva, C.; Paggi, G.M.; Bered, F.; Fay, M.F.; Lexer, C. Cross-species transfer of nuclear microsatellite markers: potential and limitations. Mol. Ecol. 2007, 16, 3759-3767.

28. Waterson, G.A. Allele frequencies after a bottleneck. Theor. Popul. Biol. 1984, 26, 387-407.

29. Luikart, G.; Cornuet, J.M. Empirical evaluation of a test for identifying recent bottlenecked populations from allele frequency data. Conservat. Biol. 1998, 12, 228-237. 
30. Torii, H.; Sato, S.; Hamaguchi, M.; Henmi, Y.; Yamashita, H. The comparison of shell morphology and genetic relationship between Meretrix lusoria and M. petechialis in Japan and Korea. Plankton Benthos Res. 2010, 5, 231-241.

31. Yamakawa, Y.A.; Imai, H. Hybridization between Meretrix lusoria and the alien congeneric species M. petechialis in Japan as demonstrated using DNA markers. Aquat. Invasions 2012, 7 , 327-336.

32. Morgan, T.S.; Rogers, A.S. Specificity and sensitivity of microsatellite makers for the identification of larvae. Mar. Biol. 2001, 139, 967-973.

33. Lu, X.; Wang, H.; Liu, B.; Lin, J. Microsatellite-based genetic and growth analysis for a diallel mating design of two stocks of the clam, Meretrix meretrix. Aquat. Res. 2012, 43, 260-270.

34. Lu, X.; Wang, H.; Liu, B.; Xiang, J. An effective method for parentage determination of the clam (Meretrix meretrix) based on SSR and COI markers. Aquaculture 2011, 318, 223-228.

35. Li, Q.; Liu, S.K.; Kong, L.F. Microsatellites within genes and ESTs of the Pacific oyster Crassostrea gigas and their transferability in five other Crassostrea species. Electron. J. Biotechnol. 2009, 12, 15-16.

36. Asahida, T.; Kobayashi, T.; Saitoh, K.; Nakayama, I. Tissue preservation and total DNA extraction from fish at ambient temperature using buffers containing high concentration of urea. Fish. Sci. 1996, 62, 727-730.

37. Marshall, T.C.; Slate, J.; Kruuk, L.E.B.; Pemberton, J.M. Statistical confidence for likelihood-based paternity inference in natural population. Mol. Ecol. 1998, 7, 639-655.

38. Rousset, F. Genepop 007: A complete reimplementation of the Genepop software for Windows and Linux. Mol. Ecol. Resour. 2008, 8, 103-106.

39. Rice, W.R. Analyzing tables of statistical tests. Evolution 1989, 43, 223-225.

40. Van Oosterhout, C.; Hutchinson, W.F.; Wills, D.P.M.; Shipley, P. MICRO-CHECKER: Software for identifying and correcting genotyping errors in microsatellite data. Mol. Ecol. Notes 2004, 4, 535-538.

41. Goudet, J. FSTAT, A program to estimate and test gene diversities and fixation indices (Version 2.9.3). 2001. Available online: http://www.unil.ch/izea/software/fstat.html (accessed on 16 July 2012).

(C) 2012 by the authors; licensee MDPI, Basel, Switzerland. This article is an open access article distributed under the terms and conditions of the Creative Commons Attribution license (http://creativecommons.org/licenses/by/3.0/). 